\title{
Faktor Yang Mempengaruhi Ibu Dalam Memilih Penolong Persalinan Di Puskesmas XIII Koto Kampar I
}

\section{Factors Affecting In Choosing The Birth Mother In Health Care Delivery XIII Koto Kampar I}

\section{Nurhapipa, Zurni Seprina}

Magister IKM STIKes Hang Tuah Pekanbaru

\begin{abstract}
ABSTRAK
Pemanfaatan pertolongan persalinan oleh tenaga profesional (bidan) di masyarakat masih sangat rendah dibandingkan dengan target yang diharapkan. Pemilihan penolong persalinan merupakan faktor yang menentukan terlaksananya proses persalinan yang aman. Determinan pemilihan penolong persalinan meliputi faktor pendidikan, pengetahuan, sikap, status ekonomi, keterjangkauan, dan dukungan keluarga oleh tenaga kesehatan dan dukun bayi. Penelitian ini bertujuan untuk menganalisis faktor yang mempengaruhi ibu dalam memilih penolong persalinan di Puskesmas XIII Koto Kampar I. Jenis penelitian menggunakan survei dengan pendekatan potong lintang. Populasi adalah seluruh ibu yang sudah melahirkan bayi hidup atau mati dalam 6 bulan terakhir dari bulan OktoberDesember 2012 sampai bulan Januari-Maret 2013 di wilayah kerja puskesmas XIII koto Kampar I sebanyak 71 ibu dan seluruh populasi dijadikan sampel. Semua variabel menggunakan uji regresi logistik berganda. Hasil penelitian menunjukkan bahwa faktor sikap $(\mathrm{p}=0,011)$, keterjangkauan $(\mathrm{p}=0,001)$ dan dukungan keluarga $(\mathrm{p}=0,042)$ berpengaruh terhadap pemilihan penolong persalinan. Variabel yang paling dominan berpengaruh terhadap pemilihan penolong persalinan adalah keterjangkauan dengan nilai koefisien regresi 2,702.
\end{abstract}

Kata Kunci: Sikap, Keterjangkauan, Dukungan Keluarga, Penolong Persalinan

\section{ABSTRACT}

The utilization of birth assistance by a professional health worker (midwife) in the community is very low compared to the target expected.The determinants of choosing birth attendant include the factors of education, knowledge, attitude, economic status, affordability, health worker and traditional birth attendant. The purpose of this survey study with cross-sectional approach was to analyze the factor of determinant influencing the mothers in choosing birth attendant at Puskesmas (Community Health Center) XIII Koto Kampar I, Kampar Subdistrict, in 2013. The population of this study was all of the 71 mothers who gave birth (born alive or stillborn) in the past 6 (six) months from October 2012 to March 2013 in the working area of Puskesmas XIII Koto Kampar I and all of the mothers were selected to be the samples for this study. All of the variables were analyzed Multiple Logistic Regression tests. The result of this study showed that the factors of attitude $(p=0.011)$, affordability $(p=0.001)$, and family support $(p=0.042)$ had influence on choosing birth attendant. Affordability was the most dominant variable influencing the process of choosing birth attendant with regression coefficient of 2.702 .

Keywords: Attitude, Affordability, Family Support, Birth Attendant

\section{PENDAHULUAN}

Masalah Kesehatan Ibu dan Anak (KIA) masih merupakan masalah kesehatan di Indonesia.Berbagai upaya telah dilakukan untuk mereduksi AKI(Angka Kematian Ibu) di Indonesia antara lain meningkatkan pelayanan antenatal di semua fasilitas pelayanan kesehatan dengan mutu yang baik serta menjangkau semua kelompok sasaran, meningkatkan pertolongan persalinan oleh tenaga profesional secara berangsur, meningkatkan deteksi dini risiko tinggi ibu hamil dan melaksanankan sistem rujukan serta meningkatkan pelayanan neonatal dengan mutu yang baik. Tujuan akhir dari program KIA tersebut menurunkan angka kematian ibu dan anak (Depkes RI, 2007).

Salah satu faktor yang memengaruhi AKI (Angka Kematian Ibu) dan AKB (Angka Kematian Bayi) adalah tenaga penolong Persalinan, setiap menit seorang perempuan meninggal karena komplikasi yang terkait dengan kehamilan dan persalinannya. Dengan kata lain, 1400 perempuan meninggal setiap hari atau atau lebih dari 500.000 perempuan meninggal setiap tahun karena kehamilan dan persalinan (WHO, 2005).

\footnotetext{
${ }^{1}$ Alamat korespondensi: Nurhapipa, Email: nurhapipa_090487@yahoo.co.id, Hp : 0852658 24677, Simpang 3 Pekanbaru
} 
Semakin tinggi cakupan persalinan oleh tenaga kesehatan semakin rendah risiko terjadinya kematian. Survei Sosial Ekonomi Nasional (SUSENAS) dari tahun 2000-2005, penolong persalinan yang dilakukan oleh dukun mencapai 26,28\% (BPS, 2006). Penolong persalinan di Indonesia sebagian besar dilakukan oleh Bidan (58\%) dan dukun bersalin $(25,31 \%)$, sedangkan menurut tipe daerah di perkotaan maupun di pedesaan penolong persalinan yang terbanyak dilakukan oleh bidan, masing-masing $65,81 \%$ dan $52,22 \%$ (BPS, 2008).

Salah satu upaya pemerintah dalam rangka mempercepat penurunan Angka Kematian Ibu adalah dengan mendekatkan pelayanan kebidanan kepada setiap Ibu yang membutuhkan. Untuk itu sejak tahun 1990 telah ditempatkan bidan di desa dengan polindesnya. Dengan penempatan bidan di desa ini diharapkan peranan dukun makin berkurang sejalan dengan makin tingginya pendidikan dan pengetahuan masyarakat dan tersedianya fasilitas kesehatan, namun pada kenyataannya masih banyak persalinan yang tidak ditolong oleh bidan melainkan oleh dukun. Departemen kesehatan RI memperkirakan bahwa pertolongan persalinan oleh dukun masih mendominasi terutama didaerah pedesaan yaitu mencapai $75 \%$ sampai $80 \%$ (Julianto, 2009).

Berdasarkan laporan dari tiga Puskesmas di Kecamatan XIII Koto Kampar pada tahun 2012 ditemukan pelayanan antenatal masih rendah, yaitu kunjungan pertama (K1) ibu hamil ke tempat pelayanan kesehatan hanya mencapai $77,9 \%$ dan kunjungan ke-4 (K4) hanya 65,8\%. Seharusnya pencapaian K1 90\% dan K4 80\%, untuk Kabupaten Kampar, cakupan pertolongan persalinan oleh tenaga kesehatan sekitar(50,10\%). Cakupan pertolongan persalinan oleh tenaga kesehatan di Puskesmas XIII Koto Kampar I Pada tahun 2012 jumlah persalinan diwilayah kerja puskesmas XIII Koto Kampar I adalah 128 orang $(15,42 \%)$, dari jumlah tersebut $31(20 \%)$ ditolong oleh dukun dan 97 (80\%) ditolong oleh tenaga kesehatan.

Pemanfaatan pertolongan persalinan oleh tenaga profesional (bidan)di masyarakat masih sangat rendah dibandingkan dengan target yang diharapkan.Hal ini disebabkan oleh faktor ibu seperti pengetahuan, sikap terhadap pemilihan penolong persalinan, untuk memanfaatkan tenaga ahli dalam pertolongan persalinan, serta jangkauan kepelayanan kesehatan, sedangkan menurut Kristiani (2006), perubahan pola pencarian pelayanan kesehatan lebih didominasi oleh tingkat keparahan penyakit yang dideritanya, persepsi minimnya fasilitas kesehatan yang modern di Indonesia, tenaga kesehatan yang tidak berkualitas, dan perilaku tenaga kesehatan yang tidak ramah,dan cenderung memilih-milih (Juliwanto, 2009).

Berdasarkan hasil survei awal pada bulan November 2012, melalui wawancara kepada beberapa ibu bersalin yang berobat ke puskesmas, diketahui bahwa adasebagian ibu hamil di tempat dia tinggal melakukan pertolongan persalinan padadukun, dengan pertimbangan faktor status ekonomi, di mana mereka mempunyai persepsibahwa jika melakukan pertolongan persalinan oleh bidan atau dokter membutuhkan biaya yang besar dibandingkan dengan pertolongan persalinan oleh dukun bayi.Untuk menganalisis faktor determinan yang mempengaruhi ibu dalam memilih penolong persalinan di Puskesmas XIII Koto Kampar I Kabupaten Kampar Tahun 2013. Kelebihan Penelitian ini bagi Puskesmas sebagai bahan masukan kepada pihak puskesmas sehingga dapat melakukan konseling atau berupa penyuluhan kepada ibu-ibu untuk memilih bidan sebagai penolong persalinan yang dapat dijadikan sebagai masukan dalam peningkatan kualitas pelayanan kebidanan, bagi peneliti menambah pengetahuan dan pengalaman peneliti khususnya yang berkaitan dengan faktor-faktor yang memengaruhi ibu bersalin dalam memilih penolong persalinan dan dapat mengaplikasikan ilmu riset yang telah dipelajari.

\section{METODE PENELITIAN}

Jenis penelitian adalah survei dengan pendekatan potong lintang (cross sectional). Lokasi penelitian di Puskesmas Wilayah Kerja Puskesmas XIII Koto Kampar I Kabupaten Kampar. Populasi adalah ibu yang sudah melahirkan bayi hidup atau mati dalam 6 bulan terakhir tercatat pada laporan puskesmas dari bulan Oktober 2012 dan tercatat pada laporan bidan pada bulan Maret 2013 sebanyak 71 ibu. Sampel penelitian ini berjumlah 71 ibu dengan menggunakan teknik pengambilan sampel yaitu total sampling.

\section{HASIL}

\section{Karakteristik Responden}

Karakteristik responden yang dilihat meliputi umur, jumlah anak, riwayat persalinan, pendidikan, pekerjaan, dan penghasilan. Berdasarkan umur $\geq 35$ tahun terdapat sebanyak 48 orang $(67,6 \%)$ dan umur $<35$ tahun terdapat sebanyak 23 orang $(32,4 \%)$. Jumlah anak yang dimiliki ibu paling banyak $>2$ orang anak yaitu sebanyak 40 orang $(56,3 \%)$ dan paling seidkit $\leq 2$ orang anak sebanyak 31 orang $(43,7 \%)$. Riwayat persalinan paling banyak ibu tidak mengalaminya sebanyak 57 orang $(80,3 \%)$ dan yang mengalami 14 orang $(19,7 \%)$. Untuk pekerjaan mayoritas ibu bekerja sebagai ibu rumah tangga sebanyak 24 orang $(33,8 \%)$ dan paling sedikit sebagai PNS yaitu 9 orang $(12,7 \%)$. Tingkat pendidikan ibu paling banyak berpendidikan tinggi (SMA, DIII, S1) yaitu sebanyak 42 orang $(59,2 \%)$ dan yang paling sedikit berpendidikan rendah (SD, SMP) yaitu sebanyak 29 orang $(40,8 \%)$. Sedangkan ibu yang status ekonomi tinggi lebih banyak $(54,9 \%)$ dari pada yang status ekonomi rendah 
$(45,1 \%)$. Hasil penelitian tersebut dapat dilihat pada Tabel 1.

Hubungan Pengetahuan, Sikap, Pendidikan, Status Ekonomi, Keterjangkauan, Dukungan Keluarga Terhadap Pemilihan Penolong Persalinan.

Berdasarkan tujuh variabel (pengetahuan, sikap, pendidikan, status ekonomi, keterjangkauan, dukungan keluarga) yang diteliti ternyata diperoleh tiga variabel yang berhubungan signifikan dengan pemilihan penolong persalinan yaitu sikap $(\mathrm{p}=0,003)$, keterjangkauan $(\mathrm{p}=0,001)$, dan dukungan keluarga $(\mathrm{p}=0,006)$, (Lihat Tabel 2).

Pengaruh Pengetahuan, Sikap, Pendidikan, Status Ekonomi, Keterjangkauan dan Dukungan Keluarga terhadap Pemilihan Penolong Persalinan

Hasil analisis uji regresi logistik juga menunjukkan bahwa variabel sikap $(p=0,011)$, keterjangkauan $\quad(p=0,001), \quad$ dan dukungan keluarga $(p=0,042)$ berpengaruh terhadap pemilihan penolong persalinan. Variabel yang paling dominan adalah variabel keterjangkauan yaitu pada nilai koefisien regresi $\mathrm{B}=2,702$. Probabilitas ibu yang memiliki sikap kurang, tidak terjangkau dan tidak mendapat dukungan keluarga memiliki probabilitas sebesar $91,9 \%$ untuk pemilihan penolong persalinan dengan dukun bayi. Sedangkan ibu yang memiliki sikap baik, keterjangkauan baik dan mendapat dukungan keluarga memiliki probabilitas sebesar 2,9\% untuk pemilihan penolong persalinan dengan dukun bayi. (Lihat Tabel 3).

Tabel 1

Distribusi Frekuensi Karakteristik Responden di Puskesmas XIII Kota Kampar I

\begin{tabular}{llcc}
\hline No & Variabel Individu & n & \% \\
\hline 1 & Umur & & \\
& $<35$ tahun & 23 & 32,4 \\
& 235 tahun & 48 & 67,6 \\
2 & Jumlah Anak & & \\
& $\leq 2$ anak & 31 & 43,7 \\
& $>2$ anak & 40 & 56,3 \\
3 & Riwayat persalinan & & \\
& Tidak ada & 57 & 80,3 \\
& Ada & 14 & 19,7 \\
4 & Pekerjaan & 9 & 12,7 \\
\hline & PNS & 22 & 31,0 \\
& Wiraswasta/Pegawai swasta & 16 & 22,5 \\
& Buruh/Petani & 24 & 33,8 \\
& Ibu rumah tangga & & \\
5 & Pendidikan & 42 & 59,2 \\
& Tinggi (SMA, DIII, S1) & 29 & 40,8 \\
& Rendah (SD, SMP) & & \\
6 & Status ekonomi & 39 & 54,9 \\
& Tinggi & 32 & 45,1 \\
\hline & Rendah & & \\
\hline
\end{tabular}

Tabel 2

Hubungan Pengetahuan, Sikap, Pendidikan, Status Ekonomi, Keterjangkauan, Dukungan Keluarga dengan Pemilihan Penolong Persalinan

\begin{tabular}{|c|c|c|c|c|c|c|c|c|}
\hline \multirow{3}{*}{ Variabel } & \multicolumn{4}{|c|}{ Pemilihan Penolong Persalinan } & \multirow{2}{*}{\multicolumn{2}{|c|}{ Jumlah }} & \multirow{3}{*}{$p$} & \multirow{3}{*}{$\chi^{2}$} \\
\hline & \multicolumn{2}{|c|}{ Tenaga Kesehatan } & \multicolumn{2}{|c|}{ Dukun Bayi } & & & & \\
\hline & $\mathbf{n}$ & $\%$ & n & $\%$ & $\mathbf{N}$ & $\%$ & & \\
\hline \multicolumn{9}{|l|}{ Pengetahuan } \\
\hline Baik & 27 & 61,4 & 17 & 38,6 & 44 & 100,0 & \multirow{2}{*}{0,276} & \multirow{2}{*}{1,188} \\
\hline Kurang & 13 & 48,1 & 14 & 51,9 & 27 & 100,0 & & \\
\hline \multicolumn{9}{|l|}{ Sikap } \\
\hline Baik & 26 & 74,3 & 9 & 25,7 & 35 & 100,0 & \multirow{2}{*}{0,003} & \multirow[b]{2}{*}{9,039} \\
\hline Kurang & 14 & 38,9 & 22 & 61,1 & 36 & 100,0 & & \\
\hline \multicolumn{9}{|l|}{ Pendidikan } \\
\hline Tinggi (SMA, DIII, S1) & 25 & 59,5 & 17 & 40,5 & 42 & 100,0 & \multirow{2}{*}{0,515} & \multirow{2}{*}{0,424} \\
\hline Rendah (SD, SMP) & 15 & 51,7 & 14 & 48,3 & 29 & 100,0 & & \\
\hline \multicolumn{9}{|l|}{ Status Ekonomi } \\
\hline Tinggi & 22 & 56,4 & 17 & 43,6 & 39 & 100,0 & \multirow{2}{*}{0,989} & \multirow[b]{2}{*}{0,001} \\
\hline Rendah & 18 & 56,3 & 14 & 43,8 & 32 & 100,0 & & \\
\hline \multicolumn{9}{|l|}{ Keterjangkauan } \\
\hline Terjangkau & 27 & 79,4 & 7 & 20,6 & 34 & 100,0 & \multirow[t]{2}{*}{0,001} & \multirow[t]{2}{*}{14,121} \\
\hline Tidak terjangkau & 13 & 35,1 & 24 & 64,9 & 37 & 100,0 & & \\
\hline \multicolumn{9}{|l|}{ Dukungan Keluarga } \\
\hline Mendukung & 25 & 75,8 & 8 & 24,2 & 33 & 100,0 & \multirow[t]{2}{*}{0,002} & \multirow[t]{2}{*}{9,453} \\
\hline Tidak mendukung & 15 & 39,5 & 23 & 60,5 & 38 & 100,0 & & \\
\hline
\end{tabular}




\section{Tabel 3}

Pengaruh Sikap, Keterjangkauan dan

Dukungan Keluarga terhadap Pemilihan Penolong Persalinan

\begin{tabular}{ccccc}
\hline Variabel & B & Sig. & Exp B & $\mathbf{9 5 \% ~ C l ~}$ \\
\hline Sikap & 1,874 & 0,011 & 6,513 & $1,543-27,503$ \\
Keterjangkauan & 2,702 & 0,001 & 14,914 & $3,479-63,941$ \\
Dukungan Keluarga & 1,353 & 0,042 & 3,870 & $1,052-14,239$ \\
Constant & $-3,504$ & - & - & - \\
\hline
\end{tabular}

\section{PEMBAHASAN}

\section{Pemilihan Penolong Persalinan}

Dalam penelitian ini menunjukkan bahwa $56,3 \%$ ibu memilih penolong persalinan oleh tenaga kesehatan dibandingkan penolong persalinan oleh dukun bayi yaitu sebesar $43,7 \%$. Keadaan ini mencerminkan bahwa ibu hamil yang bersalin di Puskesmas XIII Koto Kampar I Kecamatan Kampar lebih memilih tenaga kesehatan dari pada dukun bayi, namun hal tersebut perlu diwaspadai karena $43,7 \%$ ibu malah memilih dukun bayi sehingga berdampak terhadap angka kematian ibu atau bayi.

Hal tersebut jika dikaitkan dengan data sekunder, bahwa cakupan pertolongan persalinan oleh tenaga kesehatan sekitar $(50,10 \%)$. Cakupan pertolongan persalinan oleh tenaga kesehatan di Puskesmas XIII Koto Kampar I Pada tahun 2012 jumlah persalinan diwilayah kerja puskesmas XIII Koto Kampar I adalah 128 orang $(15,42 \%)$, dari jumlah tersebut 31 (20\%) ditolong oleh dukun dan 97 (80\%) ditolong oleh tenaga kesehatan.

Hasil penelitian ini sejalan dengan penelitian Juliwanto (2009) yang menunjukkan bahwa 78,2\% ibu memilih pertolongan persalinan oleh bidan dibandingkan penolong persalinan oleh dukun bayi yaitu sebesar $21,8 \%$. Demikian pula dengan penelitian Amilda (2010) yang menyatakan bahwa 55,6\% responden memilih pertolongan persalinan oleh dukun bayi dan $44,4 \%$ memilih pertolongan persalinan oleh bidann.

\section{Pengaruh Sikap Ibu terhadap Pemilihan Penolong Persalinan di Puskesmas XIII Koto Kampar I}

Sikap ibu terhadap pemilihan penolong persalinan yang telah dibahas sebelumnya menunjukkan bahwa 50,7\% memiliki sikap kurang baik, sedangkan 49,3\% memiliki sikap baik. Hal ini menunjukkan bahwa adanya respon yang tidak setuju dari ibu terhadap penolong persalinan oleh dukun bayi tidak dilakukan pelatihan, maka kemungkinan besar ia akan memilih dukun bayi untuk penolong persalinan.

Hasil Uji Chi square didapatkan $p=0,003$ yang berarti ada hubungan antara sikap ibu dengan penolong persalinan. Sikap baik ibu yang memilih penolong persalinan tenaga kesehatan sebesar $74,3 \%$ dan yang memilih dukun bayi sebesar $25,7 \%$. Ibu yang memiliki sikap kurang yang memilih tenaga kesehatan sebesar $38,9 \%$ dan yang memilih dukun bayi sebesar $61,1 \%$.

Hasil penelitian ini sejalan dengan penelitian Juliwanto (2009) yang menunjukkan ada hubungan signifikan antara sikap ibu dengan pengambilan keputusan penolong persalinan dengan nilai sebesar 5,111 , artinya ibu bersalin yang memilih dukun bayi 5 kali mempunyai sikap kurang setuju dibandingkan ibu bersalin dengan sikap setuju. Namun hasil regresi logistik tidak menunjukkan pengaruh signifikan dengan pemilihan pertolongan persalinan.

\section{Pengaruh Keterjangkauan Ibu terhadap Pemilihan Penolong Persalinan di Puskesmas XIII Koto Kampar I}

Berdasarkan hasil penelitian ini, di Puskesmas XIII Koto Kampar I diperoleh 52,1\% yang tidak terjangkaudan $47,9 \%$ yang terjangkau. Bahwasanya ibu lebih banyak mengatakan tempat tinggal ibu jauh dari lokasi pelayanan kesehatan $(54,9 \%)$ dan terdapat $53,5 \%$ yang ada petugas kesehatan di lingkungan tempat tinggal ibu, ini berarti bahwa variabel jarakatau keterjangkauan sarana signifikan mempengaruhi ibu untuk memlih penolong persalinan. Sebagian besar responden yang tidak terjangkau aksesnya memilih dukun bayi untuk menolong persalinannya. Responden yang memilih pertolongan persalinan oleh dukun bayi umumnya merupakan masyarakat yang jarak rumahnya menuju tempat dukun bayi lebih dekat sedangkan responden yang memilih pertolongan persalinan oleh bidan.

Terdapat hubungan yang signifikan antara keterjangkauan dengan pemilihan penolong persalinan. Ibu yang memiliki keterjangkauan lebih banyak yang memilih penolong persalinan tenaga kesehatan dibanding yang tidak terjangkau, namun dilihat dari yang memilih penolong persalinan oleh dukun bayi lebih banyak yang tidak terjangkau. Ketersediaan dan kemudahan menjangakau tempat pelayanan, akses terhadap sarana kesehatan dan trasportasi merupakan salah satu pertimbangan keluarga dalam pengambilan keputusan mencari tempat pelayanan kesehatan. Hal ini sesuai dengan penelitian Rohani (2011) yang menyatakan bahwa keterjangkauan, sarana pelayanan kesehatan dengan pemilihan tenaga kesehatan dalam penolong persalinan. Penelitian yang dilakukan oleh 
Girma,dkk (2011), mengatakan bahwa faktor terkait lainnya dalam pemanfaatan pelayanan kesehatan antara lain biaya transportasi, jarakke pusat kesehatan terdekat atau rumah sakit,dan biaya pengobatan yang dirasakan.

Ada pengaruh keterjangkauan terhadap pemilihan penolong persalinan. Jika tidak terjangkau maka kemungkinan untuk memilih penolong persalinan dukun bayi15 kali lebih besar dibanding dengan yang terjangkau. Penelitian Musadad dkk (1999) menyimpulkan bahwa pemilihan tenaga penolong persalinan dipengaruhi oleh tingkat keterjangkauan (akses) terhadap pelayanan persalinan yang tersedia, jumlah dan jenis penolong persalinan yang ada serta keterjangkauan penolong persalinan. Penelitian ini menemukan bahwa sebesar 94,0\% persalinan di pedesaan dilakukan di rumah penduduk karena kurangnya sarana pelayanan persalinan. Penelitian Amilda (2010) menyimpulkan bahwa terdapat hubungan yang bermakna antara tingkat pengetahuan, status ekonomi, dan keterjangkauan sarana kesehatan dengan pemilihan pertolongan persalinan oleh dukun bayi. Hasil penelitian ini sejalan dengan penelitian Amilda (2010) didapatkan bahwa $55,6 \%$ responden terjangkau aksesnya menuju sarana kesehatan terdekat (bidan). Sedangkan $44,4 \%$ akses menuju sarana kesehatan terdekat tidak terjangkau.

\section{Pengaruh Dukungan Keluarga Ibu terhadap Pemilihan Penolong Persalinan di Puskesmas XIII Koto Kampar I Kecamatan Kampar \\ Dari hasil distribusi frekuensi ditemukan} bahwa $46,5 \%$ ibu yang mendapat dukungan keluarga untuk pemilihan penolong persalinan, secara persentase penolong persalinan yang tidak memperoleh dukungan yang lebih tinggi dibanding ibu yang mendapat dukungan. Tidak sejalan dengan penelitian Abraham (2010) di Ethopia dukungan suami yang lebih tinggi sebesar $77 \%$ dan dukungan dari petugas kesehatan sebesar $61 \%$.

Dari 33 ibu yang didukung keluarga, ada 25ibu $(75,8 \%)$ memilih penolong persalinan dengan tenaga kesehatan dan 8 ibu $(24,2 \%)$ memilih dukun bayi. 38 ibu yang tidak didukung keluarga ada 15ibu (39,5\%) memilih penolong persalinan tenaga kesehatan dan 23 ibu $(60,5 \%)$ memilih dukun bayi. Hasil uji analisis menunjukkan ada hubungan antara dukungan keluarga ibu dengan pemilihan penolong persalinan dengan nilai $p=0,002$.

Berdasarkan hasil uji regresi logistik diperoleh bahwa variabel dukungan keluarga berpengaruh terhadap pemilihan penolong persalinan dengan nilai Exp (B) sebesar 3,870, sehingga dapat disimpulkan bahwa ibu yang tidak memiliki dukungan mempunyai kemungkinan 4 kali lebih besar untuk memilih penolong persalinan dukun bayi dibanding dengan ibu yang memiliki dukungan keluarga.
Suami dan keluarga memiliki peranan penting dalam memilih penolong selama kehamilan, persalinan, dan nifas. Hal ini terutama terjadi pada perempuan yang relatif muda usianya sehingga kemampuan mengambil keputusan secara mandiri masih rendah. Mereka berpendapat bahwa pilihan orang yang lebih tua adalah yang terbaik karena orang tua lebih berpengalaman daripada mereka. Selain itu, kalau mereka mengikuti saran orang tua, jika terjadi sesuatu yang buruk, maka seluruh keluarga dan terutama orang tua akan ikut bertanggung jawab. Oleh karena itu ketika orang tua menyarankan memilih dukun, mereka akan memilih dukun ataupun sebaliknya. Hal ini agak berbeda dengan perempuan yang lebih dewasa usianya.

\section{KESIMPULAN}

Ada pengaruh sikap dalam pemilihan penolong persalinan di Puskesmas XIII Koto Kampar I. Jika ibu yang mempunyai sikap kurang baik yaitu masih kurang pentingnya mempersiapkan proses persalinan sejak dini, maka semakin besar ibu untuk memilih dukun bayi. Ada pengaruh keterjangkauan dalam pemilihan penolong persalinan di Puskesmas kampar XIII Koto Kampar I. Jika pelayanan kesehatan tidak terjangkau yaitu jarak tempat tinggal jauh dari lokasi puskesmas, maka semakin besar keputusan ibu memilih dukun bayi. Ada pengaruh dukungan keluarga dalam pemilihan penolong persalinan di Puskesmas kampar XIII Koto Kampar I. Jika ibu yang tidak mendapat dukungan yaitu keluarga yang tidak mau menyediakan waktu untuk mendampingi ibu dalam persalinan, maka semakin besar keputusan ibu memilih dukun bayi. Variabel yang paling dominan mempengaruhi pemilihan penolong persalinan adalah keterjangkauan artinya jika keterjangkauan ibu tidak baik maka peluang untuk memilih penolong persalinan dukun bayi lebih besar 15 kali dibanding dengan ibu yang memiliki keterjangkauan baik.

\section{SARAN}

Kepada Dinas Kesehatan Kampar melalui Puskesmas XIII Koto Kampar I agar memberikan pembinaan dan pelatihan kepada seluruh dukun bayi yang ada di wilayah kerjanya tentang pertolongan persalinan yang sehat dan dibekali dengan peralatan medis yang steril dan kepada petugas kesehatan Puskesmas XIII Koto Kampar agar mengintensifkan pelaksanaan penyuluhan-penyuluhan kesehatan khususnya penyuluhan tentang pentingnya pemeriksaan dan pertolongan persalinan oleh tenaga medis seperti bidan. 


\section{DAFTAR PUSTAKA}

Amilda, NL, 2010. Faktor-Faktor yang Berhubungan dengan Pemilihan Pertolongan Persalinan oleh Dukun Bayi Program Pendidikan Sarjana Kedokteran Fakultas Kedokteran Universitas Diponegoro, Semarang

Badan Pusat Statistik. 2008 (BPS) Provinsi Sumatera Utara, Indikator Ekonomi, Berbagai Tahun Penerbitan

Depkes RI. RI. 2007. Profil Kesehatan Indonesia Tahun 2006, Jakarta

Girma F, Jira C, dan Girma B. 2011. HealthServices Utilization and AssociatedFactors in Jimma Zone, South WestEthiopia. (Online), http://www.ajol.info/index.php/ejhs/article/vie wFile/74273/64920, diakses pada tanggal 29 Mei 2013

Juliwanto, E. 2009. Faktor-Faktor yang Mempengaruhi Keputusan Memilih Penolong Persalinan Pada Ibu Hamil di Kecamatan Babul Rahmah Kabupaten Aceh Tenggara Tahun 2008. Tesis Fakultas Kesehatan Masyarakat Pascasarjna Universitas Sumatera Utara. Medan
Kristiani, M. 2006. Hubungan Pemanfaatan Bidan dengan Cakupan Program Kesehatan Ibu dan Anak Puskesmas di Kabupaten Lombok Barat, Lombok tengah, dan Lombok Timur Provinsi Nusa Tenggara Barat. Working Paper MahasiswaYogyakarta

Musadad, A; Trihono; Gotama, IBG; Rahajeng, E ; Anwar, E dan Kasnodihardjo, 1999, Peningkatan Peran Suami dan Orangtua dalam Upaya Kesehatan Ibu di Propinsi Nusa Tenggara Timur', Laporan Penelitian. Badan Penelitian dan Pengembangan Kesehatan bekerjasama dengan Direktorat Peranserta Masyarakat Ditjen Binkesmas. Jakarta

Rohani dkk, 2011. Asuhan Kebidanan Pada Masa Persalinan, Salemba Medika, Jakarta 